\title{
The Study on the Current Situation of College Students' Innovation and Entrepreneurship in the Internet Era
}

\author{
Meng Yuanyuan \\ Marxism college of Xi'an University of Science and Technology, Xi’an, Shaanxi, China, 710054
}

Keywords: "Internet +" era; innovation and entrepreneurship; ability training

\begin{abstract}
Innovation and entrepreneurship education is the driving force for China's economic development. But at present, there are still many problems in the initial stage. The purpose of this study is mainly based on the characteristics of the current "Internet + " era. This paper analyzes the current situation of college students' innovation and entrepreneurial ability in China and the methods, principles and approaches to the cultivation of college students' ability. This paper aims to analyze the current problems existing in the college students' innovative undertaking ability training, find a road more in line with the contemporary era background of "Internet +" to cultivate students' ability and quality.
\end{abstract}

\section{Introduction}

Currently, China's research on innovation and entrepreneurship education is mostly research on students' entrepreneurial topics. However, there are still large gaps in the systematic and professional cultivation of college students' innovation and entrepreneurial ability. Under the background of "Internet +", the content of education capacity cultivation is even less. Based on the above situation, this paper aims to improve the education way of innovation and entrepreneurship in Chinese universities by means of diversified and multi-level methods. Chinese colleges and universities train college students' innovative consciousness and innovative thinking mode for promoting the cultivation of college students' ability. This kind of training will enable college students to have a new era of innovative thinking of high quality talents when they start their own businesses or enter the society.

\section{Current Situation of College Students' Innovation and Entrepreneurship}

At the end of the 20th century, China's ministry of education first defined "entrepreneurship education" and then promulgated the plan of action for the revitalization of education. The purpose of this plan is to increase the level of attention of Chinese universities innovation and entrepreneurship education. And then encourage college students to start their own businesses. With the implementation of the plan, Chinese universities provide an exchange platform for college students to innovate and start their own businesses by promoting the way of university entrepreneurship program competition. And then provide the opportunity of practice for colleges and universities across the country. In 1999, China's first "challenge cup" college student entrepreneurship competition was successfully held. It is a sign that Chinese universities attach great importance to the innovation and entrepreneurship of college students. And college students are eager to participate in innovation and entrepreneurship activities. With the success of the first session, universities then set up a demonstration base and incubation park for daily college students innovation and entrepreneurship education and training.

As can be seen from figure 1 , with the development of education for college students innovation and entrepreneurship in Chinese universities, more and more universities and students have participated in the "challenge cup" China college students' entrepreneurship program competition. This is a sign that innovation and entrepreneurship education is gradually gaining support from college students, and is constantly getting the independent participation of college students. 
Table 1 The Chinese college students' business plan competition

\begin{tabular}{lllll}
\hline & The year & The organizer & $\begin{array}{l}\text { Number of participating } \\
\text { universities }\end{array}$ & $\begin{array}{l}\text { Number } \\
\text { of entries }\end{array}$ \\
\hline The first time & 1999 & The group central & 120 & 400 \\
The second time & 2000 & The group central & 137 & 455 \\
The third time & 2002 & The group central & 244 & 542 \\
The fourth time & 2004 & The group central & 276 & 603 \\
The fifth time & 2006 & The group central & 313 & 605 \\
The sixth time & 2008 & The group central & 364 & 600 \\
The seventh time & 2010 & The group central & 374 & 640 \\
The eighth time & 2012 & The group central & 390 & 650 \\
The ninth time & 2014 & The group central & 420 & 740 \\
\hline
\end{tabular}

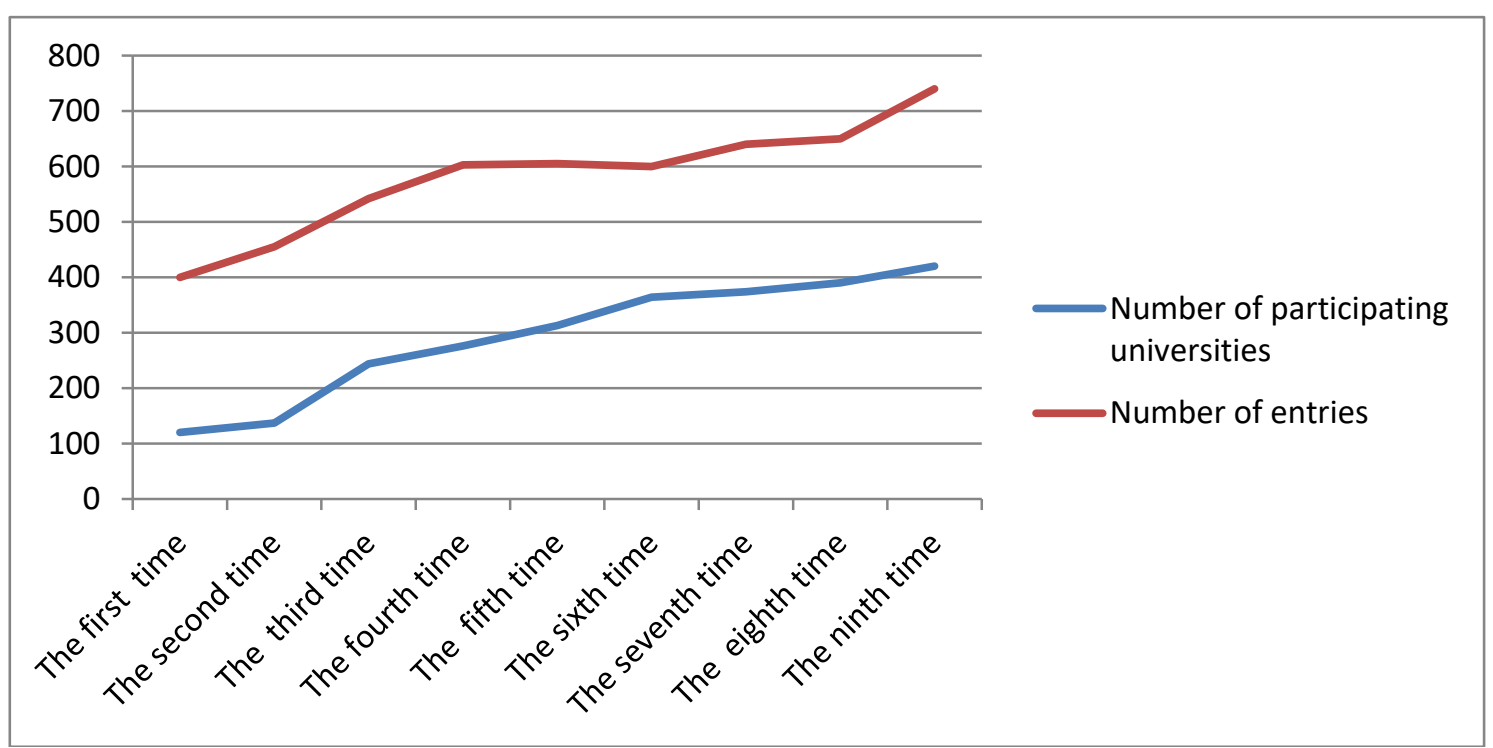

Figure 1. The participating institutions and projects of each "challenge cup" Chinese college students' business plan competition

\section{Problems of College Students' Innovation and Entrepreneurship}

\subsection{Weak innovation and entrepreneurship}

Although the Chinese government and universities are pushing graduates to start their own businesses, the current university also take the employment rate of graduates as the priority, and the employment rate is the strategic direction of talent cultivation. Moreover, the innovation and entrepreneurship competition held is only a project of utility, and it is not really integrated into the stage of innovation and entrepreneurship. This kind of quick profit and profit mentality shows the students' weak awareness of innovation and entrepreneurship, and does not realize the real purpose of holding the entrepreneurship competition.

\subsection{Lack of innovation ability practice.}

Innovation and entrepreneurship has become the key strategy of the current era. And the education has become an important way to respond to the national call. Some Chinese universities are unwilling to invest capital and energy in innovation and entrepreneurship practice, which leading to the innovation and entrepreneurship of universities education is only on the surface level. This phenomenon leads to the lack of practical experience in the innovation ability of Chinese university students, which will reduce students' enthusiasm.

\subsection{Lack of entrepreneurial ability.}

Students in some colleges and universities do not fully understand the theoretical knowledge of 
innovation and entrepreneurship education, which will lead to their ignorance of how to start a business. And in the process of starting a business, how to run your own company, this situation will inevitably lead to the failure of entrepreneurship, which is also the main reason for the failure of most startups. Some scholars have investigated the challenge cup entrepreneurship competition. The results show that 57 percent of students do not know the purpose and content of the challenge cup entrepreneurship competition. And the entry requirements are unknown. However, because the students involved in the project are still small, there are still a lot of limitations for the entrepreneurial projects to participate in. Due to the lack of publicity and limitation of the university's propaganda, students' awareness of innovation and entrepreneurship is lacking. Ultimately, they lack the entrepreneurial ability.

\section{The Cause Analysis of the Problems in the Cultivation of College Students' Innovation and Entrepreneurship Ability}

\subsection{Insufficiently important Innovation and entrepreneurship education}

Innovation and entrepreneurship education is the driving force for China's economic development. Despite years of development, there are still many problems in the initial stage. Chinese students have accepted the idea of education from their childhood. Since primary school, they have focused their learning on theoretical knowledge in classroom books. The importance and necessity of innovation and entrepreneurship education are not profound, and lack of correct guidance from the state and schools. Teachers with professional innovation and entrepreneurial ability and quality often adhere to some old teaching theories to mislead the innovation and entrepreneurship of college students. Which cause college students to wander on the wrong path of innovation and entrepreneurship. It is because universities and students don't pay much attention to innovation and entrepreneurship education, which causes students to enter the society and cannot solve the problems of operation. In a word, it is because the education system in China has not attached importance to innovation and entrepreneurship education since primary school. Which leads to the lack of awareness of innovation and entrepreneurship education, and the lack of entrepreneurial ability will inevitably lead to the failure of entrepreneurship.

\subsection{Unsound innovation and entrepreneurship education environment}

Although China's current innovation and entrepreneurship education has been strongly supported by the Chinese government, the innovation and entrepreneurship education environment and atmosphere in universities are still relatively backward, and the impact on graduates of contemporary universities is still relatively small. In this traditional education innovation, it is necessary to find the right way to renovate China's traditional education. Chinese colleges and universities must strengthen education environment and form a good atmosphere of innovation and entrepreneurship. A good atmosphere of innovation and entrepreneurship will expand students' understanding of it and enhance their innovative entrepreneurial ability and comprehensive quality.

\subsection{Lack of the system of innovation and entrepreneurship education}

At present, the education mode of innovation and entrepreneurship in China is still only strengthened in some aspects, and it has not formed a separate system to cultivate the innovation and entrepreneurial ability of college students. Some colleges and universities just take innovation and entrepreneurship education as an elective course in college students' training system. And through ordinary lectures or competitions, we can broaden our horizon, and there is no system of combining theory with practice. This will only lead to the innovation and entrepreneurship of education, which will stay on the surface of society, which has great limitations on education capacity cultivation. The professional course of college students is a single education, so universities will not attach importance to elective courses, which will undoubtedly result in the closure of university students' thinking. Innovation and entrepreneurship education is not an overnight education. It requires the Chinese government, universities and society to work together 
to establish a complete training system of education. Chinese universities must combine theoretical knowledge with social practice to make innovation and entrepreneurship education complete system.

\section{Conclusion}

Actively exploring the establishment of education system of university students will certainly help to improve the innovation and entrepreneurship ability of college students. Colleges and universities should set up "Internet +" innovation and entrepreneurship education platform for students. In order to foster and support the innovation and entrepreneurship of the Internet era.

\section{References}

[1] Amabile T M. Motivating Creativity in Organizations: On Doing What You Love and Loving What You Do. California Management Review (2014), p. 39 - 58

[2] Robinson, P. B. Sexton, E.A. The Effect of Education and Experience on Smalland Entrepreneurial Success. Journal of Business Verturing (2014), p. 141 - 156

[3] Potter J. Entrepreneurship and Higher Education: Future Policy Directions. Sourceoecd Education \& Skills volume (2013), p. 422 - 448

[4] Shanes. Prior Knowledge and the Discovery of Entrepreneurial Opportunities. Organization Science (2010), p. 448 - 469

[5] Semra Guven. World Conference on Edueational Seiences New primary edueationcourse programmes and entrepreneurship. Proeedia Social and Behavioral Seiences (2009), p. 265-270

[6] HelgeBerglann; EsPenR Moen, KnutRoed, etal. Entre PreneurshiP: Origins and returns. Labour Eeonomies (2011), p. 180-193

[7] Roediger Voss. Thorsten Gruberjsabelle Szmigin."Service quality in higher education: Therole of student expectations". Journal of Business- Research (2007), p. 949-959 